\title{
Strategi Pengembangan Usaha Peternakan Ayam Ras Pedaging (Broiler) di Kecamatan Teluk Pandan Kabupaten Kutai Timur
}

\author{
Rusmiyati ${ }^{1}$ \\ 1Staf Pengajar Program Studi Agribisnis,Sekolah Tinggi Pertanian Kutai Timur \\ Email: rusmiyati@stiperkutim.ac.id
}

\begin{abstract}
The purpose of this research is to know the total cost, and income of broiler farm business in Teluk Pandan Sub-district of East Kutai Regency and to find $R$ / C ratio and strategy of broiler business development in Teluk Pandan Sub-district, East Kutai Regency. The number of samples in this study were 5 broiler breeders. The results of this study indicate that the total production during the period of May 2017 was 51,336.25 kilograms with an average harvest of 10267.25 kilograms. 5\% mortality bonus is not counted in acceptance because the breeder is difficult to pursue the figure. Selling price Rp.18.000, - / kg. The total revenue of May 2017 is Rp.924.052.500, - with an average revenue of Rp.184.810.500, -. Another acceptance is from the manure of $R p$. 12.550.000, -, so the total receipts to Rp.936.602.500, Total cost incurred in the broiler business is Rp.848.813.312, - or the average cost of 169,762,662, -, so the total income of $\mathrm{Rp} .87 .789 .312$, - and the average income of breeders is Rp. 17.557.838, -. The value of the Cost Ratio (RCR) of the broiler business in Teluk Pandan Subdistrict is 1,101 which means that every Rp 1, - the money used in the business will generate revenue of Rp.1,101, - and profit of Rp.0, 1011. Based on SWOT analysis, alternative strategies that can be applied in broiler business development in Teluk Pandan Sub-district of East Kutai Regency are as follows: 1) Utilizing cooperation of DOC availability and feed to develop existing business in order to fulfill the high demand of broiler; 2) Increasing partnership partnerships with livestock companies in terms of product pricing; 3) Improve product quality and rearrange the scale of business to face competition and avoid decreasing purchasing power; 4) Improving partnership pattern in capital to improve facilities and preparation of production raw materials in order to compete.
\end{abstract}

Keywords: Total cost, Revenue, Revenue, Return Cost ratio, SWOT

\begin{abstract}
ABSTRAK
Tujuan penelitian ini adalah untuk mengetahui jumlah biaya, dan pendapatan usaha peternakan ayam ras pedaging di Kecamatan Teluk Pandan Kabupaten Kutai Timur serta mencari $\mathrm{R} / \mathrm{C}$ rasio dan strategi pengembangannya usaha ayam ras pedaging di Kecamatan Teluk Pandan Kabupaten Kutai Timur. Jumlah sampel pada penelitian ini adalah 5 peternak ayam broiler. Hasil penelitian ini menunjukkan bahwa total produksi selama periode bulan Mei 2017 adalah 51.336,25 kilogram dengan panen rata-rata 10267,25 kilogram. Bonus mortalitas 5\% tidak dihitung dalam penerimaan karena peternak sulit untuk mengejar angka tersebut. Harga jual Rp.18.000, - $/ \mathrm{kg}$. Total penerimaan bulan Mei 2017 adalah Rp.924.052.500,- dengan rata-rata penerimaan Rp.184.810.500,-. Penerimaan yang lain adalah dari hasil pupuk kandang sebesar Rp. 12.550.000,-, sehingga total penerimaan menjadi Rp.936.602.500,-.Total biaya yang dikeluarkan dalam bisnis ayam broiler adalah sebesar Rp.848.813.312,- atau rata rata biaya 169.762.662,-, sehingga total pendapatan sebesar Rp.87.789.312,dan rata-rata pendapatan peternak adalah sebesar Rp. 17.557.838,- . Nilai Cost Ratio (RCR) dari bisnis ayam broiler di Kecamatan Teluk Pandan adalah 1,101 yang artinya bahwa setiap Rp 1,- uang yang digunakan dalam bisnis akan menghasilkan penerimaan sebesar Rp.1,101, - dan laba sebesar Rp.0,1011. Berdasarkan analisis SWOT, bahwa strategi alternatif yang dapat diterapkan dalam pengembangan bisnis ayam broiler di Kecamatan Teluk Pandan Kabupaten Kutai Timur adalah sebagai berikut: 1) Memanfaatkan kerjasama ketersediaan DOC dan pakan untuk mengembangkan usaha yang telah ada agar dapat memenuhi tingginya permintaan ayam ras pedaging; 2) Meningkatkan kerjasama kemitraan dengan perusahaan
\end{abstract}


peternakan dalam hal penentuan harga produk; 3) Meningkatkan kualitas produk dan menata kembali skala usaha untuk menghadapi persaingan dan menghindari penurunan daya beli; 4) Meningkatkan pola kemitraan dalam permodalan untuk memperbaiki sarana dan persiapan bahan baku produksi agar dapat bersaing.

Kata Kunci: Total biaya, Penerimaan, Pendapatan, Return Cost ratio Return Cost ratio, SWOT

\section{Pendahuluan}

Peternakan ayam ras pedaging (broiler) mulai dirintis perkembangannya sejak tahun 1960, yaitu sejak dimulainya program Bimas Ayam. Tahun 1970—1980, peternakan ayam ras mengalami pertumbuhan yang pesat dengan ditandai tumbuhnya investasi pada industri hulu (bibit, pakan, dan obat-obatan), hilir maupun usaha budi daya.

Perkembangan yang pesat tersebut belum diikuti dengan penataan perangkat hukum yang memadai sehingga timbul ketimpangan struktur antara usaha kecil dan besar. Oleh karena itu, periode 1980-1989 ditetapkan kebijakan Keppres No. 50 tahun 1981 tanggal 2 Nopember 1981 tentang pembinaan usaha peternakan ayam ras. Kepres tersebut merupakan suatu upaya restrukturisasi usaha dan stabilisasi perunggasan, termasuk di dalamnya usaha peternakan ayam ras pedaging. Tahun 1990 telah dikeluarkan Keppres No. 22 tahun 1990 tentang kebijaksanaan pembinaan usaha peternakan ayam ras dengan mengatur bahwa usaha ayam ras diutamakan untuk usaha peternakan rakyat, yaitu perorangan, kelompok, dan koperasi.

Adapun swasta nasional dalam usaha budi daya peternakan ayam ras harus bekerja sama dengan peternakan rakyat. Sejak saat itulah peternakan ayam ras dengan konsep agribisnis mulai berkembang ditandai dengan pesatnya pertumbuhan ayam ras, termasuk ayam ras pedaging (broiler).

Tahun 2009 dikeluarkan UU No. 18 tahun 2009 tentang Peternakan dan Kesehatan yang kini menggantikan UU No. 6 tahun 1967. Hingga tahun 2012 pemerintah masih terus mengupayakan penyusunan produk hukum sebagai pelaksanaan dari UU No. 18 tahun 2009.

Usaha peternakan unggas di Indonesia semakin berkembang, hal ini tercermin dari posisinya sebagai usaha yang handal, karena memberikan sumbangan terhadap peningkatan pendapatan, lapangan pekerjaan, pemenuhan kebutuhan gizi masyarakat dan penopang sektor industri. Upaya peningkatan peternakan ayam ras pedaging sebagai bisnis tetap dilakukan, dengan tujuan meningkatkan pendapatan para peternak dan adanya peluang kerja. Namun strategi apa yang perlu dilakukan untuk peningkatan bisnis tersebut, maka perlu dilakukan analisis SWOT.

Analisis SWOT adalah identifikasi berbagai faktor untuk merumuskan strategi perusahaan. Analisis ini didasarkan pada logika yang dapat memaksimalkan kekuatan (strengts) dan peluang (opportunities), namun secara bersamaan dapat meminimalkan 
kelemahan (weakness) dan ancaman (threats). Keputusan strategis perusahaan perlu pertimbangan faktor internal yang mencakup kekuatan dan kelemahan maupun faktor eksternal yang mencakup peluang dan ancaman. Oleh karena itu perlu adanya pertimbangan-pertimbangan penting untuk analisis SWOT (David, 2004).

Faktor kekuatan dan kelemahan terdapat dalam suatu perusahaan, sedang peluang dan ancaman merupakan faktor-faktor lingkungan yang dihadapi oleh perusahaan yang bersangkutan. Jika dapat dikatakan bahwa analisis SWOT merupakan instrumen yang ampuh dalam melakukan analisis strategi, keampuhan tersebut terletak pada kemampuan para penentu strategi perusahaan untuk memaksimalkan peranan faktor kekuatan dan pemanfaatan peluang sehingga berperan sebagai alat untuk meminimalisasi kelemahan yang terdapat dalam tubuh perusahaan dan menekan dampak ancaman yang timbul dan harus dihadapi (Robinson, 1997; 231).

Daging ayam merupakan daging favorit di Negara kita, karena hampir 100\% masyarakat Indonesia mengkonsumsi daging ayam. Sehingga berbisnis ternak ayam merupakan peluang yang cukup menguntungkan untuk di kembangkan. Ada 5 peternak ayam broiler di Kecamatan Teluk Pandan, hal ini merupakan ukuran yang cukup besar, sehingga peternak harus memiliki strategi pemasaran. Banyak rumah makan dan hampir seluruh orang suka makan ayam, merupakan kesempatan pengembangan bisnis ayam broiler. Peternak ayam broiler di Kecamatan Teluk Pandan bermitra dengan perusahaan yang menyiapkan bibit (DOC) dan pakan. Peternak menyiapkan kandang dan peralatan makan,serta obat-obatan dan biaya pemeliharaan. Pendapatan peternak berasal dari penjualan ayam yanga langsung dibeli oleh perusahaan dengan harga $\mathrm{Rp}$ $18.000,-/ \mathrm{kg}$ atau diperkirkan $50 \%$ harga pasar. Namun dengan kesediaan DOC dan pakan yang dijamin keberadaannya, peternak memiliki kesempatan untuk meningkatkan usahanya.

Permasalahan yang dapat dikemukakan yaitu berapakah jumlah biaya, penerimaan dan pendapatan usaha peternakan ayam ras pedaging di Kecamatan Teluk Pandan Kabupaten Kutai Timur serta bagaimanakah efisiensi dan alternatif strategi pengembangan usaha yang tepat untuk diaplikasikan pada peternakan ayam ras pedaging di Kecamatan Teluk Kabupaten Kutai Timur. Tujuan penelitian ini adalah untuk mengetahui jumlah biaya, dan pendapatan usaha peternakan ayam ras pedaging di Kecamatan Teluk Pandan Kabupaten Kutai Timur serta mencari R/C rasio dan strategi pengembangannya usaha ayam ras pedaging di Kecamatan Teluk Pandan Kabupaten Kutai Timur. 


\section{$2 \quad$ Metode Penelitian}

Penelitian ini adalah penelitian diskriptif kuantitatif. Jenis penelitian ini adalah observational dengan disain Cross Sectional Study. Metode yang digunakan adalah metode survey dengan alat bantu kuesioner dan wawancara.

\section{Desain, Lokasi dan Waktu}

Penelitian ini dengan pendekatan kuantitatif, penelitian survey ini menggunakan kuesioner sebagai alat bantu. Wilayah penelitian adalah di Kecamatan Teluk Pandan Kabupaten Kutai Timur.

\section{Teknik Sampling}

Unit pengamatan terkecil yang diamati pada penelitian ini adalah peternak ayam broiler. Jumlah peternak di Kecamatan Teluk Pandan adalah sebanyak 5 peternak. Penentuan jumlah sampel secara sengaja yaitu dengan metode purposive sampling, dikarenakan keadaan jumlah anggota populasi hanya 5 peternak, sehingga seluruh anggota populasi dijadikan sampel.

\section{Jenis dan Teknik Pengumpulan Data}

Data yang terkumpul merupakan data primer yang mencakup biaya produksi, jumlah produksi, dan harga produk. Data ini diperoleh melalui wawancara dengan menggunakan instrumen kuesioner.

\section{Teknik Analisis Data}

Ada lima hal pokok yang dianalisis dalam penelitian ini yaitu analisis biaya, penerimaan dan pendapan, serta analisis $\mathrm{R} / \mathrm{C}$ rasio dan analisis strategi pengembangan, namun didalam analisis akan dimulai dengan analisis penerimaan dan pendapatan selanjutnya analisis kelayakan usaha dan analisis strategi pengembangan usaha dengan SWOT.

Teknik analisis data yang digunakan dalam penelitian ini adalah sebagai berikut :

1. Analisis Biaya

Menurut Soedarsono (1995), untuk mengetahui jumlah biaya yang dikeluarkan dalam kegiatan usaha adalah sebagai berikut:

Total Biaya (TC) dengan rumus TC $=$ TFC + TVC

Keterangan :

TC : Total cost/biaya produksi

TFC : :Total fixesd Cost/ Total Biaya Tetap

TVC : Total Variabel Cost/Total Biaya Variabel

\section{Analisis Pendapatan}

Mubyarto (1994), menjelaskan bahwa pendapatan dihitung dengan cara mengurangkan total penerimaan dengan total biaya, dengan rumus sebagai berikut: 


$$
\mathrm{I}=\mathrm{TR}-\mathrm{TC}
$$

Keterangan :

I : Income/Pendapatan

TR: Total Revenue/Total Penerimaan

TC : Total cost/Biaya Total

3. Analisis Penerimaan:

Menurut Sukirno (2002), untuk mengehitung jumlah penerimaan yang diperoleh dapat diketahui dengan menggunakan rumus :

$$
\mathrm{TR}=\mathrm{P} . \mathrm{Q}
$$

Keterangan :

TR : Total Revenue/Total Penerimaan

P : : Price/Harga Produk

Q : Jumlah Produk.

4. Analisis $\mathrm{R} / \mathrm{C}$ rasio

R/C Ratio (Revenue Cost Ratio) merupakan efisiensi usaha, yaitu ukuran perbandingan antara Penerimaan usaha $($ Revenue $=R)$ dengan Total Biaya $($ Cost $=T C)$. Dengan nilai $\mathrm{R} / \mathrm{C}$, dapat diketahui apakah suatu usaha menguntungkan atau tidak menguntungkan. Usaha efisiensi (menguntungkan) jika nilai $R / C>1$

Rumus :

$$
\mathbf{R} / \mathbf{C}_{\text {Rasio }}=\text { Total Penerimaan }(\mathrm{R}): \text { Total Biaya Produksi (TC) }
$$

Kriteria keputusan:

$\mathrm{R} / \mathrm{C}>1$, usahatani menguntungkan (tambahan manfaat/penerimaan lebih besar dari tambahan biaya), $\mathrm{R} / \mathrm{C}<1$, usahatani rugi (tambahan biaya lebih besar dari tambahan penerimaan), $\mathrm{R} / \mathrm{C}=1$, usahatani impas (tambahan penerimaan sama dengan tambahan biaya).

\section{Analisis SWOT}

Strategi untuk pengembangan bisnis ayam ras pedaging ini dianalisis secara deskriptif yaitu dengan mengidentifikasi faktor internal dan eksternal dengan menggunakan analisis SWOT (Strengths Weakness Opportunities Threats).

a. Analisis Faktor Internal

Faktor yang menjadi kekuatan dan kelemahan perusahaan dapat dirumuskan strategi internal dengan menggunakan matriks IFAS (Internal Factors Analisys Summary).Hasil analisis matriks IFAS yang diperoleh bertujuan untuk mengidentifikasikan seberapa besar kekuatan dan kelemahan yang dapat mempengaruhi kelangsungan usaha dari perusahaan dan respon perusahaan terhadap faktor-faktor internal tersebut. 
b. Analisis Faktor Eksternal

Faktor peluang dan ancaman perusahaan dapat dirumuskan strategi internal dengan menggunakan matriks EFAS (Eksternal Factors Analisys Summary). Hasil analisis matriks EFAS yang diperoleh bertujuan untuk mengidentifikasikan seberapa besar peluang dan ancaman yang dapat mempengaruhi kelangsungan dan respon perusahaan terhadapan faktor eksternal tersebut.

c. Matriks SWOT

Matriks yang dipakai untuk menyusun faktor-faktor strategi perusahaan adalah matriks SWOT. Matriks ini dapat menggambarkan secara jelas bagaimana peluang dan ancaman eksternal yang dihadapi perusahaan dapat disesuaikan dengan kekuatan dan kelemahan internal yang dimilikinya. Dalam matriks ini dapat menghasilkan empat set kemungkinan alternatif strategis perusahaan (Rangkuti, 2004). Berikut matrik SWOT:

Tabel 1. Matriks SWOT

\begin{tabular}{|c|c|c|}
\hline $\begin{array}{ll}\text { Faktor Eksternal } & \text { Faktor Internal } \\
\end{array}$ & $\begin{array}{c}\text { Strengths (S) } \\
\text { (Menentukan 5-10 faktor- faktor } \\
\text { kekuatan internal) }\end{array}$ & $\begin{array}{c}\text { Weakness }(\mathrm{W}) \\
\text { (Menentukan 5-10 faktor- faktor } \\
\text { kelemahan internal) }\end{array}$ \\
\hline \begin{tabular}{|c|} 
Opportunities (0) \\
\end{tabular} & Strategi( S-O) & Strategi $(\mathrm{W}-\mathrm{O})$ \\
\hline $\begin{array}{l}\text { Menentukan 5-10 faktor-faktor } \\
\text { peluang eksternal }\end{array}$ & $\begin{array}{l}\text { Menciptakan strategi yang } \\
\text { menggunan kekuatan untuk } \\
\text { memanfaat peluang yang ada }\end{array}$ & $\begin{array}{l}\text { Menciptakan strategi yang } \\
\text { meminimalkan kelemahan untuk } \\
\text { memanfaat peluang yang ada }\end{array}$ \\
\hline Treaths $(\mathrm{T})$ & Strategi( S-T) & Strategi $(\mathrm{W}-\mathrm{T})$ \\
\hline $\begin{array}{l}\text { Menentukan 5-10 faktor-faktor } \\
\text { ancaman eksternal }\end{array}$ & $\begin{array}{l}\text { Menciptakan strategi yang } \\
\text { menggunan kekuatan untuk } \\
\text { mengatasi ancaman. }\end{array}$ & $\begin{array}{l}\text { Menciptakan strategi yang } \\
\text { meminimalkan kelemahan dan } \\
\text { menghindari ancaman }\end{array}$ \\
\hline
\end{tabular}

Sumber: Rangkuti (2005)

Tahapan dalam menentukan faktor-faktor lingkungan dalam matriks IFE (Internal Factor Evaluation) dan EFE (Eksternal Factor Evaluation)adalah sebagai berikut :

1. Identifikasi faktor-faktor yang menjadi kekuatan dan kelemahan serta peluang dan ancaman dalam kolom 1.

2. Beri bobot masing-masing faktor dalam kolom 2, dengan skala mulai dari 1,00 (sangat penting) sampai dengan 0,00 (tidak penting). Pemberian bobot ini berdasarkan pada pengaruh faktor-faktor tersebut terhadap posisi strategis perusahaan. Jumlah dari pembobotan ini tidak boleh melebihi skor total yaitu 1,00.

3. Hitung rating dalam kolom 3 untuk masing-masing faktor internal maupun eksternal atau kekuatan, kelemahan, peluang dan ancaman dengan memberikan skala mulai 4 (outstanding) sampai dengan 1 (poor) berdasarkan pengaruh faktor tersebut terhadap kondisi perusahaan pada saat dilakukan penelitian. Pada matriks IFE untuk faktor yang menjadi kekuatan, skala nilai yang digunakan yaitu : $1=$ sangat lemah, 2 = lemah, $3=$ baik, 4 = sangat baik. Sedangkan untuk faktor yang menjadi kelemahan pemberian nilai rating dilakukan kebalikannya. Sedangkan matriks EFE untuk faktor yang menjadi 
peluang, skala nilai yang digunakan yaitu : $1=$ rendah (kurang respon), 2 = sedang (respon sama dengan rata-rata), $3=$ tinggi (respon di atas rata-rata), dan $4=$ sangat tinggi (respon superior). Sedangkan untuk faktor yang menjadi ancaman pemberian nilai rating dilakukan sebaliknya.

Hasilnya dari 4 (outstanding) sampai dengan 1 (poor), dan Nilai total ini menunjukkan bagaimana perusahaan tertentu bereaksi terhadap faktor-faktor strategis internal dan eksternalnya. Total skor pembobotan antara 1 sampai dengan 4.

Ketentuan pada matriks IFE, jika nilai 2.5 menunjukkan bahwa situasi internal perusahaan berada pada tingkat rata-rata, dan nilai 1 menunjukkan situasi internal perusahaan sangat buruk. Sedangkan nilai 4 mengidentifikasikan bahwa situasi internal perusahaan sangat baik.

Ketentuan pada matriks EFE, jika nilai 2.5 menunjukkan perusahaan mampu merespon situasi eksternal secara rata-rata dan nilai 1 menunjukan perusahaan tidak dapat memanfaatkan peluang dan menghindari ancaman yang ada. Sedangkan nilai 4 menunjukkan perusahaan merespon peluang maupun ancaman yang dihadapi dengan baik.

\section{Hasil dan Pembahasan}

\section{Total Biaya}

Total biaya yang dikeluarkan oleh peternak ayam broiler di Kecamatan Teluk Pandan terdiri atas biaya tetap dan biaya variabel. Berikut disajikan hasil analisis total biaya tersebut pada Tabel 2 .

Tabel 2. Total Biaya Peternakan Ayam Broiler di Kecamatan Teluk Pandan

\begin{tabular}{ccc}
\hline No. & Jenis Biaya & Total Biaya (Rp) \\
\hline 1 & Biaya Tetap & 10.841 .262 \\
\hline 2 & Biaya Variabel & 837.921 .050 \\
\hline Total Biaya & & 848.813 .312 \\
\hline Rata-rata Biaya & 169.762 .662 \\
\hline \multicolumn{2}{c}{ Sumber: Data Olahan 2017 }
\end{tabular}

Berdasarkan tabel tersebut diatas, bahwa total biaya peternakan ayam broiler di Kecamatan Teluk Pandan sebesar Rp. 848.813.312,-, sehingga biaya rata-rata tiap peternak pada periode pemeliharaan bulan Mei 2017 sebesar Rp. 169.762.662,--

\section{Penerimaan}

Penerimaan dalam beternak ayam broiler terdiri atas penerimaan hasil produksi dan penjualan kotoran ayam sebagai pupuk. Penerimaan hasil produksi merupakan hasil kali antara jumlah produksi dengan harga jual. Harga jual ayam ras pedaging pada saat penelitian ditingkat peternak sebesar Rp.18.000 per kilogram yaitu pada periode Mei 2017. Berikut penerimaan usaha ternak ayam ras pedaging di Kecamatan Teluk Pandan periode pemeliharaan Mei 2017. 
Tabel 3. Penerimaan Peternak Berdasarkan Hasil Produksi

Total Produksi Harga Jual Penerimaan $\quad$ Penerimaan Pupuk Total Penerimaan

$\begin{array}{lllll}(\mathrm{Kg}) & (\mathrm{Rp}) & \text { Produksi }(\mathrm{Rp}) & \text { Kandang }(\mathrm{Rp}) & (\mathrm{Rp})\end{array}$

\begin{tabular}{|c|c|c|c|c|}
\hline $51.336,25$ & 18.000 & 924.052 .500 & 12.550 .000 & 936.602 .500 \\
\hline
\end{tabular}

Berdasarkan Tabel 3 diatas diketahui bahwa total penerimaan usaha ternak ayam broiler di Kecamatan Teluk Pandan adalah sebesar Rp.936.602.500,- dan rata-rata penerimaan usaha ternak ayam pedaging periode Mei 2017 adalah sebesar Rp.184.810.500,--

\section{Pendapatan}

Pendapatan adalah selisih antara total penerimaan dengan total biaya. Berikut pendapatan peternak ayam pedaging di Kecamatan Teluk Pandan (Tabel 4)

Tabel 4. Pendapatan Rata-Rata Peternak Ayam Broiler di Kecamatn Teluk Pandan

\begin{tabular}{cccc}
\hline $\begin{array}{c}\text { Penerimaan } \\
(\mathbf{R p})\end{array}$ & $\begin{array}{c}\text { Total Biaya } \\
(\mathbf{R p})\end{array}$ & $\begin{array}{c}\text { Total } \\
\text { Pendapatan (Rp) }\end{array}$ & $\begin{array}{c}\text { Pendapatan } \\
\text { Rata-rata (Rp) }\end{array}$ \\
\hline 936.602.500 & & & \\
\hline Sumber: Data Olahan 2017 & 848.813 .312 & 87.789 .188 & 17.557 .838 \\
\hline
\end{tabular}

Berdasarkan Tabel 4 tersebut diatas, bahwa total pendapatan peternak ayam ras pedaging di Kecamatan Teluk Pandan adalah sebesar Rp. 87.789.188, dengan demikian rata-rata pendapatan peternak pada periode Mei 2017 adalah sebesar Rp.17.557.838,--

\section{Return Cost Ratio (RCR)}

Analisis R/C ratio digunakan untuk mengetahui apakah usahatani yang dijalankan menguntungkan atau tidak, Berikut analisis Rentrun Cost $(\mathrm{R} / \mathrm{C})$ rasio dijelasnya Tabel 5.

Tabel 5. Analisis Kelayakan Usaha Ternak Ayam Broiler

\begin{tabular}{cccc}
\hline Revenue (R) (Rp/Kg) & $\begin{array}{c}\text { Cost }(\mathbf{C}) \\
(\mathbf{R p} / \mathbf{K g})\end{array}$ & $\mathbf{R} / \mathbf{C}$ Ratio & Keterangan \\
\hline 184.810 .500 & 169.762 .662 & 1,089 & Menguntungkan \\
\hline Sumber: Data Diolah & & &
\end{tabular}

Berdasarkan analisis $\mathrm{R} / \mathrm{C}$ rasio diperoleh hasil 1,089, menunjukkan bahwa $\mathrm{R} / \mathrm{C}>$

1. Sehingga dapat disimpulkan bahwa usaha ternak ayam ras pedaging di Kecamatan Teluk Pandan menguntungkan. Hasil analisis R/C rasio tersebut menunjukkan bahwa dalam setiap 1 rupiah uang dikeluarkan pengusaha akan menghasilkan penerimaan sebesar Rp.1,089,- dan keuntungan Rp. 0,089,-.

1) Strategi Pengembangan Usaha Ternak Ayam Broiler

\section{a. Analisis IFE (Internal Factor Evaluation)}

Matrik IFE digunakan untuk mengidentifikasi faktor-faktor lingkungan internal dan mengklasifikasikannya menjadi kekuatan dan kelemahan perusahaan dengan cara melakukan pemberian bobot dan rating. Matrix IFE akan menganalisa dua variabel yaitu strength (kekuatan) dan weakness atau kelemahan, apa saja yang dimiliki oleh perusahaantersebut. Analisis IFE 
usaha ayam ras pedaging di Kecamatan Teluk Pandan dapat dilihat pada Tabel 6 berikut.

Tabel 6. Matrik IFE Usaha Ayam Ras Pedaging Di Kecamatan Teluk Pandan

\begin{tabular}{|c|c|c|c|c|c|}
\hline No. & Internal Factor & Nilai & Bobot & Rating & Skor \\
\hline \multicolumn{6}{|c|}{ Kekuatan (Strength) } \\
\hline 1 & Kualitas DOC dan pakan bagus & 1,3 & 0,13 & 4 & 0,52 \\
\hline 2 & Hubungan kemitraan bagus & 1,2 & 0,12 & 4 & 0,48 \\
\hline 3 & Mitra menjamin pemasaran & 1,3 & 0,13 & 4 & 0,52 \\
\hline 4 & Berpengalaman budiya ternak ayam pedaging & 1,2 & 0,12 & 3 & 0,36 \\
\hline 5 & Memiliki Modal Kandang sendiri & 1 & 0,10 & 4 & 0,4 \\
\hline 6 & Mitra menjamin kemudahan bahan baku & 1,1 & 0,11 & 3 & 0,33 \\
\hline & Total & & & & 2,61 \\
\hline \multicolumn{6}{|c|}{ Kelemahan (Weakness) } \\
\hline 1 & Peralatan sederhana & 0,9 & 0,09 & 3 & 0,27 \\
\hline 2 & Penetapan harga oleh mitra terlalu rendah & 0,5 & 0,05 & 1 & 0,05 \\
\hline 3 & Tugas pekerja tidak jelas & 0,9 & 0,09 & 3 & 0,27 \\
\hline 4 & Modal kerja terbatas & 0,6 & 0,06 & 2 & 0,12 \\
\hline & Total & 10,0 & \multicolumn{2}{|l|}{1,00} & 0,71 \\
\hline & Total Skor & & & & 3,32 \\
\hline
\end{tabular}

pedaging adalah 3,32. Nilai tersebut menunjukkan bahwa perusahaan berada pada posisi di atas rataan dalam hal kekuatan internal secara keseluruhan, yang berkaitan dengan kualitas bahan baku, permodalan dan budidaya yang dimiliki oleh peternak ayam ras pedaging di Kecamatan Teluk Pandan.

Faktor-faktor lingkungan internal yang dimiliki oleh usaha peternakan ayam ras pedaging di Kecamatan Teluk Pandan meliputi kekuatan dan kelemahan. Faktor penentu internal menggunakan matrik IFE untuk memperoleh bobot, rating dan skor. Menurut Rangkuti (2004), matrik IFE meringkas dan mengevaluasi kekuatan dan kelemahan utama dalam berbagai bidang fungsional dari suatu usaha dan matrik ini juga memberikan dasar untuk mengenali dan mengevaluasi hubungan diantara bidang ini. Hasil analisis matriks IFE pada tabel 6 dengan total skor sebesar 3,32, artinya secara internal usaha peternakan ayam ras pedaging di Kecamatan Teluk Pandan mampu memanfaatkan kekuatan untuk mengatasi kelemahan yang ada.

\section{b. Analisis EFE (Eksternal Factor Evaluation)}

Matrik EFE digunakan untuk merangkum peluang dan ancaman pada suatu usaha. Analisis matrik EFE dilakukan perhitungan yang sama dengan matrik IFE yaitu perhitungan terhadap bobot dan pemberian rating pada setiap faktor.

Menurut David (2004), matrik EFE membuat ahli strategis meringkas dan mengevaluasi informasi ekonomi, social, budaya, demografi, lingkungan, politik, pemerintah, hokum dan persaingan. Hasil analisis matriks EFE dalam pengembangan usaha ayam ras pedaging di Kecamatan Teluk Pandan dapat dilihat pada tabel 18. Hasil evaluasi faktor eksternal dengan menggunakan matriks EFE, diperoleh total skor pada faktor peluang 2,368, faktor ancaman 0,925 dan total skor 3,293 yang berada 
diatas rata-rata 2,5 (jika nilainya berada dibawah 2,5 menandakan bahwa secara internal perusahaan adalah lemah, sedangkan nilai yang berada diatas 2,5 menunjukan posisi eksternal yang kuat). Hal ini menunjukan bahwa usaha ternak ayam ras pedaging di Kecamatan Teluk Pandan, mampu memanfaatkan peluang yang ada dan menghindari ancaman yang muncul (David, 2004)

Tabel 7. Matrik EFE Usaha Ayam Ras Pedaging Di Kecamatan Teluk Pandan

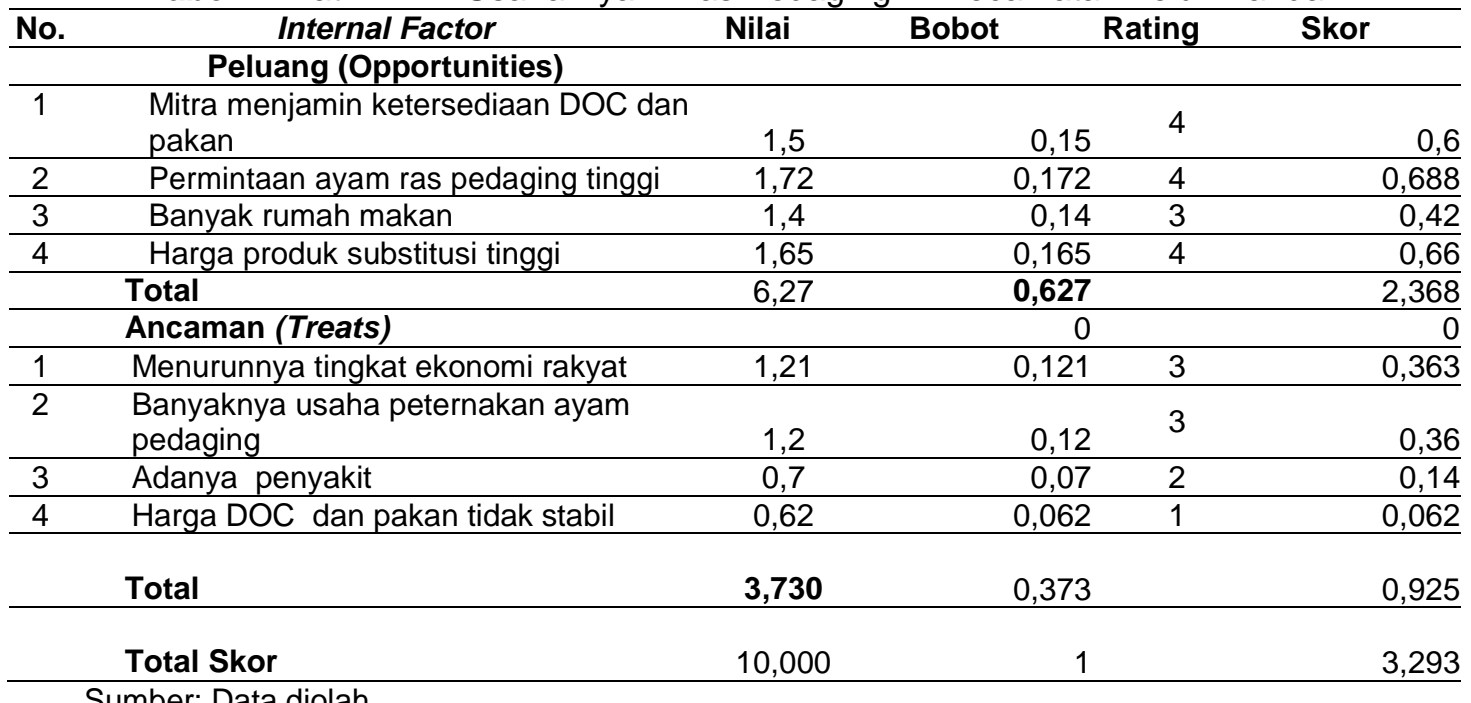

\section{c. Analisis Lingkungan Internal dan Eksternal}

Pemetaan posisi usaha dilakukan agar dapat memudahkan usaha dalam penentuan alternatif strategi pengembangan usaha yang tepat untuk menghadapi persaingan dan pertumbuhan bisnis dimasa depan. Hasil yang diperoleh dari matrik IFE dan EFE digunakan untuk menyusun matrik IE, sehingga dapat diketahui posisi usaha ayam ras pedaging di Kecamatan Teluk Pandan.

Berdasarkan nilai yang dibobotkan dalam IFE sebesar 3,320 dan yang dibobotkan dalam EFE sebesar 3,293 dapat diketahui posisi usaha ayam ras pedaging di Kecamatan Teluk Pandan Kabupaten Kutai Timur dalam matrik IE dibawah ini.

Tabel 8. Matrik Internal-Eksternal (IE) Usaha Ayam Ras Pedaging di Kecamatan Teluk Pandan Kabupaten Kutai Timur

\begin{tabular}{|c|c|c|}
\hline $\begin{array}{c}\text { GROWTH } \\
\text { Konsentrasi melalui } \\
\text { Integrasi vertikal }\end{array}$ & $\begin{array}{c}. \\
\text { GROWTH } \\
\text { Konsentrasi melalui } \\
\text { Integrasi horizontal }\end{array}$ & $\begin{array}{l}3 . \\
\text { RENTRENCHMENT } \\
\text { Turnaround }\end{array}$ \\
\hline $\begin{array}{l}\text { STABILITY } \\
\text { Hati - hati }\end{array}$ & $\begin{array}{l}\text { 5. } \\
\text { GROWTH } \\
\text { Konsentrasi melalui } \\
\text { Integrasi horizontal } \\
\text { STABILITY } \\
\text { Tak ada perubahan } \\
\text { Profit strategi }\end{array}$ & $\begin{array}{l}6 . \\
\text { RETRENCHMENT } \\
\text { Captive Company } \\
\text { Atau } \\
\text { Divestment }\end{array}$ \\
\hline $\begin{array}{l}7 . \\
\quad \text { GROWTH } \\
\text { Difersifikasi Konsentrik }\end{array}$ & $\begin{array}{l}\text { GROWTH } \\
\text { GROWhifikasi Konsentrik }\end{array}$ & $\begin{array}{c}9 \\
\text { RETRENCHMENT } \\
\text { Bangkrut atau } \\
\text { likuidasi }\end{array}$ \\
\hline
\end{tabular}


Nilai total skor pada matrik IFE sebesar 3,320 sedangkan matrik EFE memperoleh skor 3,293. Hasil tersebut menempatkan usaha ayam ras pedaging di Kecamatan Teluk Pandan pada sel 1 yang disebut strategi growt and build atau tumbuh dan berkembang. Berdasarkan posisi tersebut, strategi yang dapat dilakukan pengusaha adalah strategi integrasi horisontal (horisontal integration), yang dilakukan dengan cara mengambil alih fungsi pemasok bahan baku (backward integration) atau dengan mengambil alih fungsi distributor (forward integration). Hal ini merupakan strategi utama untuk perusahaan yang memiliki posisi kompetitif pasar yang kuat dalam industri yang sangat atraktif (David, 2009).

\section{d. Analisis SWOT}

Analisis SWOT merupakan suatu teknik perencanaan strategi yang bermanfaat untuk mengevaluasi kekuatan (strength) dan kelemahan (weakness), peluang (opportunities), dan ancaman (threats) dalam suatu proyek, baik yang sedang berlangsung maupun dalam perencanaan baru. Bagi pengusaha ayam ras pedaging matrik SWOT digunakan untuk menetapkan strategi berdasarkan kekuatan, kelemahan, peluang dan ancaman. Matrik ini menggambarkan bagaimana peluang dan ancaman eksternal yang dihadapi pengusaha ayam ras pedaging di Kecamatan Teluk Pandan disesuaikan dengan kekuatan dan kelemahan internal yang dimilikinya. Untuk lebih jelasnya dapat dilihat pada Tabel 9.

Berdasarkan hasil analisis faktor-faktor internal dan eksternal yang menjadi kekuatan dan kelemahan serta peluang dan ancaman dalam mengembangkan usaha peternakan ayam ras pedaging di Kecamatan Teluk Pandan maka ditemukan alternative strategi yang dapat dipertimbangkan sebagai berikut:

1) Strategi S-O (Strength-Opportunity) atau strategi kekuatan-peluang.

Strategi S-O dirumuskan dengan pertimbangan bahwa manajemen hendak memanfaatkan kekuatan perusahaan dan keunggulan bersaing yang dimiliki untuk mengeksploitasi peluang bisnis yang tersedia. Oleh karena itu strategi ini juga disebut maksi-maksi karena manajemen mencoba menggunakan apa yang serba positif (maksimal) yang kini dimiliki (Muhammad, 2008; 176). Alternatif strategi S-O yang dapat dirumuskan adalah :

a. Memanfaatkan kerjasama ketersediaan DOC dan pakan untuk mengembangkan usaha yang telah ada agar dapat memenuhi tingginya permintaan ayam ras pedaging.

b. Meningkatkan kerjasama yang baik dengan rumah makan dan pengepul/agen agar dapat mengimbangi kebutuhan ayam ras pedaging

c. Menekan biaya produksi dengan memanfatkan berpengalaman dalam berbudidaya agar menghasilkan produk rendah biaya 
Tabel 9. Matrik SWOT

\begin{tabular}{|c|c|c|}
\hline Eksternal & $\begin{array}{l}\text { Kekuatan (S) } \\
\text { 1. Kualitas DOC dan pakan } \\
\text { bagus } \\
\text { 2. Hubungan kemitraan bagus } \\
\text { 3. Mitra menjamin pemasaran } \\
\text { 4. Berpengalaman budidaya } \\
\text { ternak ayam pedaging } \\
\text { 5. Memiliki modal kandang } \\
\text { sendiri } \\
\text { 6. Mitra menjamin kemudahan } \\
\text { bahan baku }\end{array}$ & $\begin{array}{l}\text { Kelemahan (W) } \\
\text { 1. Peralatan sederhana } \\
\text { 2. Penetapan harga oleh mitra } \\
\text { terlalu rendah } \\
\text { 3. Tugas pekerja tidak jelas } \\
\text { 4. Modal kerja terbatas }\end{array}$ \\
\hline $\begin{array}{l}\text { Peluang (O) } \\
\text { 1. Mitra menjamin ketersediaan } \\
\text { DOC dan pakan } \\
\text { 2. Permintaan ayam ras pedaging } \\
\text { tinggi } \\
\text { 3. Banyak rumah makan } \\
\text { 4. Harga produk subsitusi tinggi } \\
\end{array}$ & $\begin{array}{l}\text { Strategi (SO) } \\
\text { 1. Memanfaatkan kerjasama } \\
\text { ketersediaan DOC dan pakan } \\
\text { untuk mengembangkan usaha } \\
\text { yang telah ada agar dapat } \\
\text { memenuhi tingginya permintan } \\
\text { ayam ras pedaging }(\mathrm{S} 1, \mathrm{O} 1) \\
\text { 2. Meningkatkan kerjasama yang } \\
\text { baik dengan rumah makan dan } \\
\text { pengepul/agen agar dapat } \\
\text { mengimbangi kebutuhan ayam } \\
\text { ras pedaging (S1, S2,S3, } \\
\text { S6,O2,O3) } \\
\text { 3. Menekan biaya produksi dengan } \\
\text { memanfatkan berpengalaman } \\
\text { budidaya agar menghasilkan } \\
\text { produk rendah biaya } \\
\text { (S4,S5,O4) }\end{array}$ & \begin{tabular}{|l} 
Strategi (WO) \\
1. Meningkatkan kerjasama \\
kemitraan dengan perusahaan \\
peternakan dalam hal \\
penentuan harga produk \\
(W1,W2, W4,O1) \\
2. Meningkatkan kerjasama \\
dengan agen pemasaran agar \\
produk \\
terpasarkan(W2,O2,O3) \\
3. Memperbaiki manajemen \\
produksi untuk efisiensi biaya \\
produksi (W3,W4, O4)
\end{tabular} \\
\hline $\begin{array}{l}\text { Ancaman (T) } \\
\text { 1. Menurunnya tingkat ekonomi } \\
\text { rakyat } \\
\text { 2.Banyaknya pengusaha } \\
\text { peternakan ayam pedaging } \\
\text { 3. Adanya penyakit } \\
\text { 4. Harga DOC dan pakan tidak } \\
\text { stabil }\end{array}$ & $\begin{array}{l}\text { Strategi (ST) } \\
\text { 1. Meningkatkan kualitas produk } \\
\text { dan menata kembali skala } \\
\text { usaha untuk menghadapi } \\
\text { persaingan dan menghindari } \\
\text { penurunan daya beli } \\
\text { (S1,S2,S3,T1,T2) } \\
\text { 2. Meningkatkan kemitraan } \\
\text { dalam persiapan bahan baku } \\
\text { untuk menghindari fluktuasi } \\
\text { harga (S2,S4,S6,T4) } \\
\text { 3. Menata pola pemeliharaan } \\
\text { untuk mengantisipasi wabah } \\
\text { penyakit (S4,S5,T3) }\end{array}$ & $\begin{array}{l}\text { Strategi (WT) } \\
\text { 1. Meningkatkan pola kemitraan } \\
\text { dalam permodalan untuk } \\
\text { memperbaiki sarana dan } \\
\text { persiapan bahan baku produksi } \\
\text { agar dapat bersaing } \\
\text { (W1,W4,T1,T2,T4) } \\
\text { 2. Pencegahan penyakit (W3,T3) } \\
\text { 3. Meningkatkan kemitraan untuk } \\
\text { menghadapi pesaing usaha } \\
\text { (W2,W4,T2) }\end{array}$ \\
\hline
\end{tabular}

Sumber: Data Diolah 2017

2) Strategi W-O (Weakness-Opportunity) atau strategi kelemahan-peluang adalah strategi untuk meminimalkan kelemahan yang ada untuk memanfaatkan peluang eksternal.

Alternatif strategi W-O yang dapat dirumuskan adalah :

a. Meningkatkan kerjasama kemitraan dengan perusahaan peternakan dalam hal penentuan harga produk

b. Meningkatkan kerjasama dengan agen pemasaran agar produk terpasarkan

c. Memperbaiki manajemen produksi untuk efisiensi biaya produksi 
3 Strategi S-T (Strength-Threat) atau strategi kekuatan-ancaman adalah strategi untuk mengoptimalkan kekuatan internal yang dimiliki dalam menghindari ancaman. Alternatif strategi S-T yang dapat dirumuskan adalah :

a. Meningkatkan kualitas produk dan menata kembali skala usaha untuk menghadapi persaingan dan menghindari penurunan daya beli.

b. Meningkatkan kemitraan dalam persiapan bahan baku untuk menghindari fluktuasi harga.

c. Menata pola pemeliharaan untuk mengantisipasi wabah penyakit.

4 Strategi W-T (Weakness-Threat) atau strategi kelemahan-ancaman adalah strategi untuk meminimalkan kelemahan internal dan menghindari ancaman eksternal. Alternatif strategi W-T yang dapat dirumuskan adalah :

a. Meningkatkan pola kemitraan dalam permodalan untuk memperbaiki sarana dan persiapan bahan baku produksi agar dapat bersaing

b. Pencegahan penyakit

c. Meningkatkan kemitraan untuk menghadapi pesaing usaha

Matriks SWOT menghasilkan dua belas alternatif strategi untuk kemajuan usaha ayam ras pedaging di Kecamatan Teluk Pandan Kabupaten Kutai Timur. Dua belas alternatif strategi tersebut dipilih empat strategi terbaik dengan pertimbangan dapat dilaksanakan oleh setiap pengusaha dan paling sesuai dengan kondisi usaha. Strategi tersebut adalah sebagai berikut:

1) Memanfaatkan kerjasama ketersediaan DOC dan pakan untuk mengembangkan usaha yang telah ada agar dapat memenuhi tingginya permintaan ayam ras pedaging.

Kerjasama atau kemitraan dengan pengusaha peternakan ayam ras pedaging akan memastikan ketersediaan DOC dan pakan ternak, sehingga akan lebih mudah untuk pengembangan atau peningkatan usaha.

2) Meningkatkan kerjasama kemitraan dengan perusahaan peternakan dalam hal penentuan harga produk.

Penentuan harga produk akan menentukan tingkan keuntungan peternak ayam ras pedaging. Jika harga terlalu rendah, maka dapat menyebabkan rendah keuntungan atau bahkan mengalamai break even point. Usaha ternak ayam ras pedaging dalam pola kemitraan tetap harus memperhatikan biaya produksi dan harga jual, sehingga diperlukan kerjasama dalam penentuan harga produk agar bisa sama-sam mendaptkan keuntungan.

3) Meningkatkan kualitas produk dan menata kembali skala usaha untuk menghadapi persaingan dan menghindari penurunan daya beli. 
Penurunan daya beli masyarakat akan menyebabkan berkurangnya permintaan terhadap ayam ras pedaging, sehingga perlu menata ulang kuantitas produksi agar tidak terjadi over produksi yang menyebabkan produk tidak terpasarkan. Kondisi ini dapat menyebabkan kerugian bagi peternak ayam ras pedaging, sehingga pada saat terjadi penurunan daya beli diperlukan penataan ulang kuantitas produksi.

4) Meningkatkan pola kemitraan dalam permodalan untuk memperbaiki sarana dan persiapan bahan baku produksi agar dapat bersaing

Usaha ayam ras pedaging di Kecamatan Teluk Pandan merupakan usaha dengan pola kemitraan, dengan pola kemitraan ini perlu peningkatan kerja sama permodalan sebagai strategi untuk memperbaiki sarana dan prasarana serta mempersiapkan bahan baku untuk produksi berikutnya karena dikhawatirkan sering terjadinya fluktuasi harga bahan baku.

\section{Kesimpulan dan Saran}

\section{Kesimpulan}

Berdasarkan hasil penelitian dan pembahasan yang telah dipaparkan sebelumnya dapat ditarik kesimpulan sabagai berikut:

a) Total biaya yang dikeluarkan oleh peternak ayam broiler di Kecamatan Teluk Pandan terdiri atas biaya tetap dan biaya variabel dengan total biaya yang dikeluarkan pada periode Mei 2017 sebesar Rp 848.813.312,- , sehingga biaya rata rata adalah sebesar $\mathrm{Rp}$ 169.762.662. Total biaya sebesar $\mathrm{Rp} 848.813 .312$,- telah digunakan untuk memproduksi ayam broiler sebanyak $51.336,25 \mathrm{~kg}$.

b) Total pendapatan yang diperoleh peternak ayam broiler pada periode pemeliharaan Mei 2017 di Kecamatan Teluk Pandan berasal dari pendapatan produksi ayam ras pedaging dan hasil jual pupuk kandang adalah sebesar Rp 87.789.186,- dengan rata-rata pendapatan sebesar $\mathrm{Rp} 17.557 .838,-$. Total pendapatan tersebut dihitung berdasarkan hasil penerimaan dari jumlah produksi sebesar $51.336,25 \mathrm{~kg}$ dengan harga per kg Rp 18.000,- dan penerimaan dari hasil pupuk kandang sebesar Rp. 12.550.000,-, sehingga diperoleh total penerimaan sebesar Rp. 936.602.500,--

c) Hasil analisis Return Cost Ratio (RCR) yang diperoleh pada usaha ternak ayam ras pedaging di Kecamatan Teluk Pandan adalah 1,08 artinya setiap Rp.1,- uang yang dikeluarkan oleh pengusaha akan menghasilkan penerimaan sebesar Rp.1,08,-.

d) Posisi usaha ayam ras pedaging (broiler) di Kecamatan Teluk Pandan Kabupaten Kutai Timur berdasarkan matriks IE berada pada sel I yang artinya tumbuh dan berkembang atau berarti posisi usaha ayam ras pedaging (broiler) berada pada posisi yang kuat dan daya tarik yang tinggi. 


\section{Saran}

Berdasarkan pembahasan hasil penelitian, maka untuk meningkatkan atau mengembangkan usaha ayam ras pedaging di Kecamatan Teluk Pandan disarankan sebagai berikut:

1. Sedapat mungkin menekan biaya pakan sejauh tidak menurunkan prosDari hasil analisis usaha biaya pakan merupakan biaya terbesar dalam usaha ayam ras pedaging. Untuk mengoptimal dan efisiensi pakan perlu dilakukan dilakukan perhitungan FCR (Feed Conversion Ratio) agar diketahui berapa kebutuhan pakan untuk berat ayam tertentu yang diinginkan.

2. Dalam pemeliharaan sebaiknya pengusaha mengikuti Standar Operasional Prosedur (SOP) yang ditetapkan dinas terkaituntuk menghindari penyakit ayam dan mortalitas.

3. Pengusaha sebaiknya melakukan pengembangan usaha dengan memperluas kandang dan kapasitas produksi untuk meningkatkan pendapatan

4. Sebaiknya kerja sama yang dilakukan dengan pengepul/agen dibuat secara tertulis guna menghindari kesalahfahaman dikemudian hari

\section{Daftar Pustaka}

David, Freddy Rangkuti. 2004. Analisis Swot Teknik Membedah Kasus Bisnis.. PT. Gramedia Pustaka Utama. Jakarta .

David, Freddy Rangkuti. 2009. Manajemen Strategi. Edisi Kesembilan. PT Intan Sejati Klaten. Jakarta

Mubyarto. 1994. Pengantar Ekonomi Pertanian. LP3ES,Jakarta. Fuad Mas'ud, 2004, "Survai Diagnosis Organisasional ," Badan Penerbit Universitas Diponegoro, Semarang.

Muhammad, Suwarsono. 2002. Manajemen Strategik. Unit Penerbit dan Percetakan Sekolah Tinggi IImu Manajemen YKPN. Yogyakarta.

Robinson, Pearce. 1997. Manajemen Stratejik Formulasi, Implementasi dan Pengendalian Jilid 1, (Jakarta : Binarupa Aksara. Jakarta.

Soedarsono. (1995). Pengantar Ekonomi Mikro. Jakarta : Lembaga Penelitian, Pendidikan dan Penerapan Ekonomi

Sukirno, Sadono. 2002. Teori Mikro Ekonomi. Cetakan Keempat Belas. Rajawali Press: Jakarta. 